\title{
A Qualitative Analysis of Healthcare Students' Perceptions Towards Online Learning due to the COVID-19 Pandemic
}

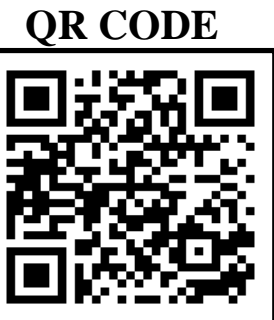

\section{KESARI SINGH*1 (D, NISHA SINGH²}

INTRODUCTION: While online learning has the ability to bring students and teachers together in the Distance Education (DE) mode, it is not feasible in the healthcare based professions.

AIM: To analyze healthcare students' perceptions towards online learning due to the COVID-19 pandemic.

MATERIALS AND METHOD: This qualitative, focus group-based study was done on the three focus groups consisting of 15 students each: medical, dental and allied sciences. Data were collected using observations from the recordings of the scheduled online interview which was approximately $30-$ minutes in length and the investigator asked questions from the pre-validated interview guide consisting of seven questions. Data was analyzed using the constant comparative method, which was then consequently categorized into two major areas: positive experiences and negative experiences. Positive experiences included: time flexibility, convenience, ease of connection and ease of learning; while negative experiences included instructor's inexperience and a lack of interaction, self-motivation, isolation and missing out on practical learning.

RESULTS: While responses of the positive experience ranged from "I have the flexibility to wake up few minutes before the lecture and directly log on for the lecture" to "Even during the closure of schools/ classes, I need not worry about lagging behind in my studies"; the negative experiences included statements like "the inexperience of the instructor in handling the teaching software led to difficulties and interruption in learning" and "I am a great loss due to missing patient work!! How am I going to become a good doctor if I don't practise on patients under supervision of my staff'.

CONCLUSION: While students are slowly adapting themselves to online based learning, those belonging to the healthcare sector are missing out on their practical classes which has the potential to hamper the quality of care being provided by them as future professionals.

KEYWORDS: COVID-19, Learning, Healthcare

\section{INTRODUCTION}

Online learning, is a boon for people to learn a new set of skills or get an education, especially in the field of distance education, which has become increasingly common in many universities worldwide as it brings the teachers and students closer. ${ }^{1}$ However, its importance in courses related to the healthcare sector is limited as these courses depend on practical based patient teaching and learning and not offered via DE mode.

However, as the world started to battle the onset of the dreaded COVID-19 pandemic, social distancing became the norm, and led to undesirable effects on practical, patient-based learning opportunities at the institutional level. With countries enforcing lockdowns as an urgent need to protect and save communities, societies, and the nation as a whole, educational institutions began to struggle and contemplate on various options to deal with such an unprecedented situation. ${ }^{2}$

The only feasible option to continue with education in such challenging times seemed to immediately adopt the online learning mode. However, while this seemed like a mundane task, researchers have previously proven that a significant challenge for university teachers has been their lack of the pedagogical content knowledge needed for teaching students via the online medium. ${ }^{3}$

Apart from teachers, researchers have reported that students were reluctant to take online courses and at times, complained about the online classes they undertook during pre-covid times. ${ }^{4}$ Therefore, the present qualitative study was undertaken to analyze healthcare students' perceptions towards online learning due to the COVID-19 pandemic.

\section{RESEARCH QUESTIONS}

1. What are the student experiences during online learning and would they like to continue with the same?

2. What factors lead the students to pay/not pay attention in their online classes?

3. What are student's reactions on missing their patient-based practical learning?

\section{MATERIALS AND METHOD}

This qualitative, focus group-based study was done on three focus groups consisting of 15 students 
each: medical, dental and allied sciences. Students were enrolled over a period of three months via a combination of convenience and volunteer sampling. Students who joined their course after 2019 were excluded from the study as they had little or no practical exposure to pre-clinical/clinical/patient work.

Participation in the study was voluntary and before taking their written consent, students were distributed an online document stating the aim and objectives of the present study as well as their role as participants. Students were assured of the confidentiality of their data and access to the recordings were only available to the primary investigator. For data analysis, other investigators were only shared an audio recording of the meeting to conceal participant identity.

Data were collected using observations from the recordings of the scheduled online interview. This allowed researchers to validate as well as crosscheck the reported data. ${ }^{5}$ The duration of the interview was approximately 30-minutes in length and the investigator asked questions from the pre-validated interview guide consisting of seven questions. To eliminate interviewer's bias, the questions were framed in a non-authoritative and non-implied nature; they were open ended in which the perceptions and experiences of the students were duly recorded without interference of any kind. Data was analyzed to answer the research questions and to cross reference similarities and differences among participants.

Extensive coding of the interview was done by the researchers using the constant comparative method. ${ }^{6}$ Data were organized around each research question, which related to experiences of students taking online classes and the factors shaping those experiences and this information was then consequently categorized into two major areas: positive experiences and negative experiences of online education. The positive experiences included: time flexibility, convenience, ease of connection and ease of learning; while negative experiences included instructor's inexperience and a lack of interaction, self-motivation, isolation and missing out on practical learning.

\section{RESULTS AND DISCUSSION}

Here, the individual positive and negative responses of the students are discussed.

\section{POSITIVE RESPONSES}

1. Time Flexibility: Time flexibility of the students was found to be the greatest aspect of online learning. Reponses ranged from "I have the flexibility to wake up few minutes before the lecture and directly log on for the lecture", "There is no worry of time being a constraint while completing assignments", "Even if I miss a class, online recording provides an easy access for me to go back and learn what I missed", "Due to any important work at home, the online recordings of lecture shared help me catch up on what I missed".

The students reported the time flexibility as a positive aspect as they reported that they has the "least distraction from the instructor as well as colleagues during the lectures and could focus solely on the topic being taught". Management of time was found to be significantly correlated with the cumulative grade point average of students as reported by Adams RV et al. $^{7}$

2. Convenience: Convenience was another positive aspect reported by the participants as it was reported by students that "The convenience of logging in from home saves time of getting ready for college and saves travelling time", "It is more convenient for me to understand concepts away from all distractions occurring in the lecture theatre" and "Online learning is more convenient as it saves me from the hassle of carrying books around the college and then run to the library/ locker room every time I forget my book(s)/material(s)". However, on the contrary, convenience has been found to be an enormous nonquality factor among students ${ }^{8}$ and has driven up online demand around the globe. ${ }^{9}$

3. Ease of connection: Reponses from students included "I can connect with my teachers and class in an instant" to "Receiving Assignments and their submission is an easy task" as well as "My fast internet makes it easier for me to understand the concept being taught in class and ask questions without delay".

4. Ease of learning: Students reported ease in learning and stated that "Even during the closure of schools/ classes, I need not worry about lagging behind in my studies", "The use of videos, interactive slides/software by my staff makes learning fun". As reported by Khan MA et al. in their study, students 
reported a positive perception towards e-learning and accepted this new learning system and stated that elearning has now established itself as a new way of enhancing the learning process among students. ${ }^{10}$

\section{NEGATIVE RESPONSES}

1. Instructor's inexperience: Students reported that "the inexperience of the instructor in handling the teaching software led to difficulties and interruption in learning" as well as "Sometimes, the equipment used by the instructor is old and causes disturbance while teaching", "Our instructor is inexperienced in muting students and some mischievous students purposefully unmute themselves or annotate on the screen" and "the instructor is inexperienced in letting students in the class after the lecture has started and various students are left in the waiting room or denied entry in the lecture". In agreement to the above statements, Ramadani A et al. reported that teachers had different experiences and challenges during online teaching, especially in assessing and evaluating and stated there is a relative difficulty to evaluate students' progress through technology.

2. Self-motivation and a lack of interaction: Students documented that "I am not motivated enough to attend the lectures whole-heartedly and have to do it for the attendance", "I am unable to motivate myself to learn from online classes due to laziness; while attending college, one had to get ready as well as interacting with friends was fun" and "Lack of interaction during lectures make me feel that the teacher is doing it for completion of course and I do not find such non-interactive teaching engaging". As per Meşe E et al., students tends to lose motivation due to differences in expectations and content as well as a lack of learning environment. ${ }^{12}$

3. Isolation: A lack of isolation was also reported by the students; and this was in combination with the lack of interaction and due its frequent repetition, isolation was taken as a separate negative entity. "I miss not interacting with my friends" to "I feel alone at home and am unable to concentrate", to "I believe in group study and due to absence of my friends am unable to do so" and "There is nobody to discuss problems and group-study". In agreement, Croft $\mathrm{N}$ et al., reported that a physical and temporal separation between the teacher and student, and between students themselves, is an important factor that leads to feelings of isolation among them. The lack of interaction and discussion between students decreases the richness of the learning experience. ${ }^{13}$
4. Missing out on practical learning: As the students belonged to health sciences, they mostly were in the practical-based learning phase of their course which dealt with patient based interaction and treatment. Students reported that "I am a great loss due to missing patient work!! How am I going to become a good doctor if I don't practise on patients under supervision of my staff", "Seeing clinical cases online and discussing them is not enough", "The whole profession of dentistry is based on patient care and I am missing out on that only!!" and "What about the pending pre-clinical quota that needs to be completed before start treating human patients" and "I am scared that my staff will not have time to concentrate on the patient care provided by me once college commences!!".

Limitations: While conducting the study, there could be a possibility of the occurrence of a "social desirability bias" by the students, even though the confidentiality of their data was assured. It has been the earnest efforts of the researchers to ensure proper coding of data though proper standardization procedures as well its careful categorization of data to avoid any bias while analysing data of qualitative nature as seen in the present study.

\section{CONCLUSION}

Based on the results of this qualitative study, it can be assumed that students are slowly adapting themselves to online based learning, although there are various challenges present. Students belonging to the healthcare sector are missing out on their practical classes and it has the potential to hamper the quality of care being provided by them as future professionals.

\section{REFERENCES}

1. Allen IE, Seaman J. Digital Learning Compass: Distance Education Enrollment Report 2017. (Online PDF). Available from: https://files.eric.ed.gov/fulltext/ED580868.pdf [Last Accessed on $18^{\text {th }}$ August 2020]

2. Rieley JB. Corona Virus and its impact on higher education. Research Gate 2020. (Online Discussion). Available from:

https://www.researchgate.net/post/Corona_Virus_an d_its_impact_on_higher_education

3. Angeli C, Valanides, N. Preservice elementary teachers as information and communication technology designers: an instructional systems design model based on an expanded view of pedagogical content knowledge. Journal of Computer Assisted 
Learning 2005; 21(4): 292-302. https://doi.org/10.1111/j.1365-2729.2005.00135.x.

4. Allen E, Seaman J. Sizing the opportunity: The quality and extent of online education in the United States, 2002 and 2003 (2003). (Online PDF). Available from: https://files.eric.ed.gov/fulltext/ED53006o.pdf. [Last Accessed on $25^{\text {th }}$ August 2020]

5. Patton MQ. Qualitative evaluation and research methods(2nd ed.) 1990; Newbury Park, CA: Sage Publications.

6. Glaser BG, Strauss AL. The discovery of grounded theory: Strategies for qualitative research. Hawthorne 1967, NY:Aldine.

7. Adams RV, Blair E. Impact of Time Management Behaviors on Undergraduate Engineering Students' Performance. SAGE Open 2019 . https://doi.org/10.1177/2158244018824506

8. Artino AR. Online or face-to-face learning? Exploring the personal factors that predict students' choice of instructional format. Internet and Higher Education 2010;13:272-6.

9. Wart VM, Ni A, Medina P, et al. Integrating students' perspectives about online learning: a hierarchy of factors. Int J Educ Technol High Educ. 2020;17:53. https://doi.org/10.1186/s41239-020-00229-8

10. Khan MA, Vivek, Nabi MK, Khojah M, Tahir M. Students' Perception towards E-Learning during COVID-19 Pandemic in India: An Empirical Study. Sustainability 2021; 13 : 57. https://doi.org/10.339o/su13010057

11. Ramadani A, Xhaferi B. Teachers' Experiences With Online Teaching Using The Zoom Platform With Efl Teachers In High Schools In Kumanova. SEEU Review 2020; 15(1): 142-55. https://doi.org/10.2478/seeur-20200009

12. Meşe E, Sevilen C. Factors influencing EFL students' motivation in online learning: A qualitative case study. Journal of Educational Technology \& Online Learning 2021;4(1):11-22. http://doi.org/10.31681/jetol.81768o

13. Croft N, Dalton A, Grant M. Overcoming Isolation in Distance Learning: Building a Learning Community through Time and Space. Journal for Education in the Built Environment 2010;5:1:27-64. http://doi.org/10.11120/jebe.2010.05010027

Cite this article as:

Singh K, Singh N. A Qualitative Analysis of Healthcare Students' Perceptions

Towards Online Learning due to the COVID-19 Pandemic. Int Healthc Res J. 2021;5(5)OR1-OR4. https://doi.org/10.26440/IHRJ/0505.08427

AUTHOR AFFILIATIONS: $\left({ }^{*}\right.$ Corresponding Author)

1. Senior Resident, Department of Dentistry, UCMS \& GTB Hospital, Delhi-110095 (https://orcid.org/oooo-0002-3883-6992)

2. Senior Resident, Department of Dentistry, UCMS \& GTB Hospital, Delhi-110095

Source of support: Nil, Conflict of interest: None declared

Contact Corresponding Author at: drkesari241288[at]gmail[dot]com 